\title{
Regional Diversification of the Productivity of the Biomass Sector in Poland in the Context of the Development of the Bio-economy
}

\author{
Jarosław GOŁĘBIEWSKI \\ Warsaw University of Life Sciences, Warsaw, Poland \\ jaroslaw_golebiewskiesggw.pl
}

\begin{abstract}
The aim of the article is to present the significance of the biomass production sector in Poland on the regional basis. The study characterises the importance of agriculture, forestry, and fishing in the economy of Polish regions and evaluates the level of regional variety of labour productivity in the sector of primary production in bio-economy. Data concerning the A section of the Polish Classification of Activities was the basis for the analysis.The analysis carried out indicated that bio-economy is an important sector in the national economy. The significance of this area is proven by the share in the employment and production potential. Comparisons with regions distinguish developed, industrialised, urbanized provinces, in which the share of fixed assets, investments, and added value of bio-economy is of minor importance in the economy of a region.
\end{abstract}

Keywords: Bio-economy, Labour Productivity, Bio-based Sectors.

\section{Introduction}

In 2012, the European Commission adopted a strategy for the sustainable use of renewable resources in the European economy entitled: "Innovating for sustainable growth: a bio-economy for Europe"[6]. In this strategy, by taking into consideration demographic processes, which take place in Europe and in the world, and problems with limited access to natural resources, the attention has been drawn to the necessity of the development of production of renewable resources in the European Union, which guarantees not only food security, but also materials, energy, and other products demanded by modern societies.

The term "bio-economy" defines a collection of sectors within the frames of national economy which conduct production and processing of renewable resources. In "The Knowledge Based Bio-Economy (KBBE) in Europe: Achievements and Challenges" report, the term "bio-economy" is defined in the following manner: "The bio-economy is the sustainable production and conversion of biomass, for a range of food, health, fibre and industrial products and energy. Renewable biomass encompasses any biological material is to be used as raw material" [4]. Thus, on the 
sectoral basis, bio-economy includes many areas of economic activity, which are involved in production and distribution of articles including components of a biological origin [5]. The most important segments of bio-economy include primary sectors of the economy such as: agriculture, forestry, fishing, which produce biomass on the basis of natural resources (soil, air, water), which is the basic resource for other areas of bio-economy such as: food production, chemical industry, pharmaceutical, cosmetic, and textile industry, but also energy production [13].

The bio-economy development strategy assumes the increase of the consumption of raw materials of biologic origin (biomass) in economy, which will have not only traditional application in food production, but also, more and more often, in the production of modern, innovative chemical, pharmaceutical products, as wells as energy and fuels of great added value [9].

The increase of the production of biomass and its effective application should contribute to the improvement of food security, conservation of natural resources, the achievement of independence from non-renewable resources and to act against climate changes [7]. Bio-economy development forces, therefore, to search for technologies, which allow to increase the production of biomass in agriculture, forestry, and fishing without prejudice to purposes related to continuous development and functioning of local ecosystems [14].

In Poland, sectors, which produce biomass (agriculture, forestry, and fishing) constitute an important element of bio-economy [8]. It is appropriate to emphasise, however, that the development of those sectors indicates significant differences in regional cross-section [10]. Source literature is full of studies, which refer to determination of regional differences in the development of agriculture. Having that said, there are not many analyses, which made an attempt to evaluate regional variety of the development of the whole sector of primary production in bio-economy involving agriculture, forestry, and fishery.

The basic purpose of the study is to evaluate regional variety of the biomass production sector in Poland involving agriculture, forestry, and fishery. The undertaken research focuses especially on the presentation of diversification of production potential of this sector amongst particular regions in Poland. Also the evaluation in differences in productivity levels of the biomass sector on the regional basis in Poland has been made.

\section{Methodology of research}

The aim of the article is to present the significance of the biomass production sector in Poland on the regional basis. The study characterises the importance of agriculture, forestry, and fishing in the economy of Polish regions and evaluates the level of regional variety of labour productivity in the sector of primary production in bioeconomy. Data concerning the A section of the Polish Classification of Activities was the basis for the analysis. Section A- agriculture, forestry and fishing involves activities related to: 
- exploitation of natural plant and animal resources, cultivation of cereals and other cultivated plants, animal raising and husbandry,

- wood cutting and forest resources harvesting,

- acquiring of animals and animal products from farms or their natural environment.

Temporal extent of research included the year of 2016. In certain cases, due to the lack of data for previous period, sources concerning 2015 or 2014 were used. Basic source materials are data and bases of The Polish Central Statistical Office and primary sources.

\section{Significance of the biomass production sector in the bio- economy supply chain}

Basic sectors of bio-economy, according to the definition adopted at the beginning of the study, consist of the following: agriculture, forestry, fishing, food industry, but also some parts of chemical, pharmaceutical, and energy industry basing on renewable raw resources. Table 1 presents the division of bio-economy into four groups of sectors and their relations with the NACE classification of economic activity applicable in the European Community.

Table 1. Specification of biobased sectors, according to NACE [13]

\begin{tabular}{|c|c|}
\hline Biomass related sectors & NACE sectors \\
\hline $\begin{array}{l}\text { Primary sector activities: } \\
\text { natural resource-based activities } \\
\text { that directly exploit the bio- } \\
\text { resources to be used as input for the } \\
\text { bio-economy }\end{array}$ & Agriculture, forestry, fishing \\
\hline $\begin{array}{l}\text { Secondary sector activities: } \\
\text { conventional users (direct users) of } \\
\text { raw agricultural products }\end{array}$ & $\begin{array}{l}\text { Food, beverages, tobacco, textile, wearing apparel, } \\
\text { leather products, (products of) wood and cork (excl. } \\
\text { furniture); articles of straw and plaiting material, } \\
\text { paper and paper, furniture, construction of buildings, } \\
\text { civil engineering (e.g. wood use for bridges) }\end{array}$ \\
\hline $\begin{array}{l}\text { Tertiary sector activities: } \\
\text { new users of renewable raw } \\
\text { materials }\end{array}$ & $\begin{array}{l}\text { Manufacture of coke and refined petroleum (e.g. } \\
\text { biofuel blends); manufacture of chemicals and } \\
\text { chemical (e.g. bio-based ethylene); manufacture of } \\
\text { basic pharmaceutical products and preparations from } \\
\text { bio-based resources; manufacture of bio-based } \\
\text { rubber and plastics; electricity, gas, steam and air } \\
\text { conditioning supply from biomass (e.g. wood chips) } \\
\text { and its derivatives (e.g. biogas) }\end{array}$ \\
\hline $\begin{array}{l}\text { Ecosystem or non-market services: } \\
\text { conventional users of green } \\
\text { resources, such as sea, parks and } \\
\text { forest }\end{array}$ & $\begin{array}{l}\text { Forestry, water supplying services, non-market } \\
\text { services of recreational and cultural activities }\end{array}$ \\
\hline
\end{tabular}


In this classification, conventional sectors of bio-economy (sector of primary production, and secondary processing of raw materials of agricultural, fishing, and forestry) are distinguished, which are connected with sectors not related directly with the production of biomass - sectors of third tier processing. Basic resources of biomass are provided by sectors of primary production that, by using natural resources (soils, water, air), produce biomass, which is a resource basis for the activity of the rest of the sectors of bio-economy.

The term "biomass" has many definitions in source literature. Mostly, it is used in the energetic context. Biomass, on the energetic basis, is the primary source of energy which is composed of all substances of plant or animal origin, which are subjected to biodegradation and which use for energetic purposes is not restricted by provisions of the law [12]. Biomass is used, most of all, for the production of heat and biofuels. On this basis, biomass is defined by certain legal acts, both those national and adopted by the European Union. The Directive 2009/28/EC of the European Parliament and of the Council indicates that biomass means the biodegradable fraction of products, waste and residues from biological origin from agriculture (including vegetal and animal substances), forestry and related industries including fisheries and aquaculture, as well as the biodegradable fraction of industrial and municipal waste [3].

Bio-economy concept, however, is not limited only to energetic use of biomass. Bio-economy means a rational production and use of renewable resources for food, feed, industrial, and energetic purposes. On such a basis, the term "biomass" includes all raw materials and production having a biological and renewable character. In official EU documents, a biomass pyramid which determines the framework for this broadened definition of biomass is defined [11] (figure 1).

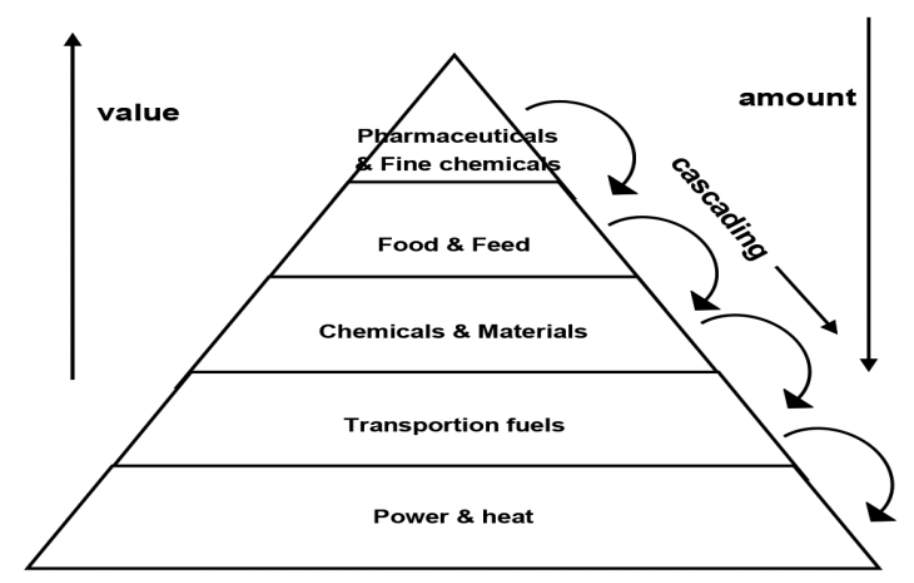

Fig. 1. The biomass pyramid [11]

Agricultural production plays a basic role in the biomass supply chain. Agricultural biomass, in the form of various agricultural products and resources, is used both for food, industrial, as well as energetic purposes. Agriculture receives plant and animal products by means of cereal cultivation and plants cultivation, as well as through 
animal raising and husbandry. Forest management constitutes an important source of biomass. It is a branch of national economy which manages the use of forest (mainly the production of wood) and activity related to the maintenance of the stability of forest stand. Additional elements of forest management are: ground cover products harvesting, spruces, medicinal plants and the realisation of non-production functions of forests, related to the protection of air, water, and soil. The third segment of the production of biomass is fishing (fishery management). It means the complex of planned and coordinated actions aimed at rational aquatic organisms management. This term involves: fishing in sea waters and the management in inland waters, (inland fishing): catching fish, crustaceans, and molluscs, as well as other aquatic organisms.

The resource of various forms of biomass produced or acquired within those three sectors of primary production is subjected to processing into final products in further links of supply chain of bio-economy. Main links, which lead production, distribution, and marketing of bio-economic products, are: food industry, feed industry, the pulp and paper-making industry, as well as sectors participating in bioenergy production. Physical, chemical, as well as biotechnological operations are applied in production processes realised in those sectors. The development of bio-economy assumes the transformation of raw materials (biomass) into more complex and value products by using various processes particularly basing on achievements of biotechnology [8].

Despite agricultural, forest production, and fishing, also waste management is an important source of biomass. Increase of the use of wastes in economic processes and their transformation into products of higher added value is the basis of the idea of the circular economy. The concept of the circular economy involves a closes cycle of the life of a product which, on a linear basis, includes the following sequence of processes: production - use- waste disposal. The effect of this approach is also reduction of a number of quantities of wastes being stored and increase of the scale of recycling [1]. This area of biomass production will not be analysed further in this study.

\section{Diversification of the bio-economy potential in Poland on a regional basis}

According to the NUTS 2 classification, there are 16 provinces in Poland. There are significant differences amongst particular provinces in terms of the level of the development of bio-economy, including also those sectors which involve the production of biomass.

Resources of the Earth are the basis for the production of biomass. In 2014, overall area of lands in Poland was 31,268.0 thousand ha (table 2), more than a half of which were agricultural lands, which covered the area of $18,717.0$ thousand ha $(59.6 \%)$. In Poland, also forest lands, as well as wooded lands cover significant area of the country - 9,369.5 thousand ha, i.e. approximately 30\% of overall area. In 2014, underwater lands covered approximately 648.5 thousand ha, which was more than $2 \%$ 
of overall area. The rest of the country is used as urbanized terrains. Wastelands and other lands were, in 2014, nearly $3 \%$ of overall area of the country.

Resources of agricultural, forest, and underwater lands indicate significant diversity in particular provinces. Acreage of agricultural lands is concentrated in Masovia province (more than $2.4 \mathrm{mil}$ ha) and in Wielkopolska Province, Lublin Province, Warmian-Masuria Province. In each of those provinces, acreage of agricultural lands is larger than 1.3 mil ha. Having said that, the smallest resources of agricultural lands are in Lubuskie Province and Opole Province, correspondingly 565 and 601 thousand ha.

Table 2. Geodetic area of the country by direction of use in 2016. [2]

\begin{tabular}{|c|c|c|c|c|c|c|c|c|}
\hline \multirow[b]{2}{*}{$\begin{array}{c}\text { Specification/ } \\
\text { Province }\end{array}$} & \multicolumn{2}{|c|}{ Total } & \multirow{2}{*}{$\begin{array}{c}\text { Agricul- } \\
\text { tural } \\
\text { land }\end{array}$} & \multirow{2}{*}{$\begin{array}{l}\text { Fo- } \\
\text { rests }\end{array}$} & \multirow{2}{*}{$\begin{array}{c}\text { Lands } \\
\text { under } \\
\text { waters }\end{array}$} & \multirow{2}{*}{$\begin{array}{c}\text { Urban } \\
\text { area } \\
\text { (\% of } \\
\text { total) }\end{array}$} & \multirow{2}{*}{$\begin{array}{l}\text { Waste- } \\
\text { land }\end{array}$} & \multirow{2}{*}{$\begin{array}{l}\text { Other } \\
\text { area }\end{array}$} \\
\hline & $\begin{array}{c}\text { in } \\
\text { thous } \\
\text {. ha } \\
\end{array}$ & $\begin{array}{c}\text { in } \\
\text { perce } \\
\text { nt }\end{array}$ & & & & & & \\
\hline Poland & 31268.0 & 100.0 & 59.9 & 30.0 & 2.1 & 5.2 & 1.5 & 1.4 \\
\hline Dolnośląskie & 1994.7 & 6.4 & 59.6 & 30.6 & 0.9 & 6.9 & 0.7 & 1.3 \\
\hline $\begin{array}{l}\text { Kujawy - } \\
\text { Pomerania }\end{array}$ & 1797.1 & 5.7 & 65.2 & 23.8 & 2.7 & 4.8 & 2.3 & 1.1 \\
\hline Lublin & 2512.2 & 8.0 & 70.1 & 23.2 & 0.8 & 3.8 & 0.9 & 1.3 \\
\hline Lubuskie & 1398.8 & 4.5 & 40.4 & 50.8 & 1.8 & 4.5 & 1.2 & 1.2 \\
\hline Łódź & 1821.9 & 5.8 & 70.6 & 21.5 & 0.6 & 5.5 & 0.8 & 1.0 \\
\hline Małopolska & 1518.3 & 4.9 & 60.9 & 29.0 & 1.4 & 6.1 & 0.8 & 1.9 \\
\hline Masovia & 3555.8 & 11.4 & 67.6 & 23.2 & 1.2 & 5.6 & 1.0 & 1.5 \\
\hline Opole & 941.2 & 3.0 & 63.9 & 27.5 & 1.4 & 6.1 & 0.4 & 0.8 \\
\hline Subcarpathia & 1784.6 & 5.7 & 52.6 & 38.3 & 1.2 & 4.6 & 0.6 & 2.8 \\
\hline Podlasie & 2018.7 & 6.5 & 60.2 & 31.2 & 1.4 & 3.7 & 2.7 & 0.9 \\
\hline Pomerania & 1831.0 & 5.9 & 50.3 & 37.2 & 4.1 & 5.2 & 2.3 & 0.9 \\
\hline Silesia & 1233.3 & 3.9 & 51.1 & 32.6 & 1.5 & 12.4 & 1.2 & 1.2 \\
\hline Świętokrzyskie & 1171.1 & 3.7 & 64.1 & 28.6 & 0.7 & 4.6 & 0.7 & 1.3 \\
\hline $\begin{array}{l}\text { Warmian- } \\
\text { Masuria }\end{array}$ & 2417.3 & 7.7 & 54.2 & 31.8 & 5.7 & 3.7 & 3.1 & 1.4 \\
\hline Wielkopolska & 2982.7 & 9.5 & 64.7 & 26.4 & 1.5 & 5.2 & 1.2 & 1.1 \\
\hline West Pomerania & 2289.2 & 7.3 & 48.9 & 36.5 & 5.2 & 4.4 & 3.3 & 1.7 \\
\hline
\end{tabular}

When it comes to forest lands, the largest resources have the following provinces: West Pomerania, Mazovia, Wielkopolska, Warmian-Masuria, and Lubuskie of area, which exceeds, in each case, the area of 700 thousand ha. On the opposite side, there are provinces as: Opole, Świętokrzyskie, Łódź, in which the area of agricultural lands is the smallest and is not larger than 400 thousand ha. The largest share of forests is in 
the Lubuskie Province, Podkarpackie Province, Pomerania Province, and West Pomerania Province. Significantly lesser forestation rate than national average is in the provinces as: Kujawy-Pomerania, Lublin, Łódź, and Masovia.

Four provinces dominate in terms of the significance of underwater lands in the structure of the area of the provinces, namely: West Pomerania, Warmian-Mazuria, Pomerania, and Kujawy-Pomerania. In those provinces, the share of water reservoirs is significantly larger than the national average which is approximately $2 \%$.

Labour resources decide about the potential and possibilities of economy. In 2016, the number of persons employed in the national economy was nearly 16.2 mil people. According to the data included in table 3, the service sector is a dominant sector in terms of share in employment.

Table 3. Employed persons by kind of activity* in 2016. [2]

\begin{tabular}{|c|c|c|c|c|}
\hline $\begin{array}{l}\text { Specification/ } \\
\text { Province }\end{array}$ & $\begin{array}{l}\text { Total in } \\
\text { thous. }\end{array}$ & $\begin{array}{c}\text { Agriculture, } \\
\text { forestry and } \\
\text { fishing in } \% \text { of } \\
\text { total }\end{array}$ & $\begin{array}{c}\text { Industry } \\
\text { and } \\
\text { constructio } \\
\text { n }\end{array}$ & Services \\
\hline Poland & 16197 & 10.5 & 31.3 & 57,8 \\
\hline Dolnośląskie & 1237 & 4.0 & 36.5 & 59,3 \\
\hline Kujawy -Pomerania & 852 & 1.4 & 31.7 & 54,6 \\
\hline Lublin & 866 & 21.4 & 24.1 & 54,3 \\
\hline Lubuskie & 427 & 6.8 & 34.0 & 59,0 \\
\hline Łódź & 1103 & 12.6 & 31.1 & 56,0 \\
\hline Małopolska & 1407 & 10.9 & 31.8 & 56,2 \\
\hline Masovia & 2457 & 10.8 & 22.9 & 65,7 \\
\hline Opole & 396 & 10.4 & 37.1 & 52,5 \\
\hline Subcarpathia & 831 & 12.9 & 32.1 & 548 \\
\hline Podlasie & 481 & 23.1 & 24.7 & 52.0 \\
\hline Pomerania & 986 & 6.3 & 32.7 & 60.8 \\
\hline Silesia & 1868 & 2.6 & 38.7 & 58.4 \\
\hline Świętokrzyskie & 513 & 19,1 & 30,0 & 50,9 \\
\hline Warmian-Masuria & 547 & 13,5 & 30,3 & 55,0 \\
\hline Wielkopolska & 1553 & 11,7 & 35,5 & 52,6 \\
\hline West Pomerania & 673 & 7,1 & 29,3 & 63,4 \\
\hline
\end{tabular}

* On the LFS (Labour Force Survey) basis; activities of non-specified type are not included in the structure by kind of activity.

The employment in this sector in the analysed year was almost 58\%. Share of agriculture, forestry and fishing sector is decreasing systematically. Despite a visible decrease of the share of the employed in the bio-economy sector, there are still significantly more people employed in this sector than in other countries of the EU. According to data of 2016, the share of people employed in agriculture and other 
spheres of the production of biomass has increased slightly above 10\%. Employment in the bio-economy sectors is quite clearly regionally varied. The smallest share of the employed in the bio-economy sector in comparison with the overall employment rate in the whole economy of a region exists in the Silesia Province (2.6) and in the areas, in which state agricultural farms were dominating before the transformation of the political system, that is, in Pomerania, West Pomerania, Lower Silesia, and Lubuskie provinces (share from 4 to $7.1 \%$ ). The largest share, which is larger than $20 \%$ exists in the provinces of the eastern part of Poland, including, among others, Podlasie Province- 23\%, and Lublin Province - 21.4\%. Those terrains characterise with relatively low urbanisation level and the domination of family farming based on individual farms.

According to absolute values, the largest number of people employed in bioeconomy was in the Mazovia Province - more than 265 thousand people, Lublin Province - 185 thousand, and Wielkopolska Province - 181 thousand. Large numbers of people employed in bio-economy occurs also in Lesser Poland Province (154 thousand), and Łódź Province (139 thousand). Having that said, the smallest number of people are employed in the bio-economy in Lubuskie Province (29 thousand), Opole Province (41 thousand), and West Pomerania Province (48 thousand).Fixed assets resources constitute another factor deciding about production potential of bioeconomy. This is one of the factors, which has an influence on production results and productivity of labour. Share of fixed assets in the sectors which compose bioeconomy in the value of fixed assets in total, in Poland, were 4.4\% in 2016. This share is large in typically agricultural provinces. With the average value of $4.4 \%$ for Poland, the share of more than $10 \%$ characterises Podlaskie Province, WarmianMasuria Province (8.7\%), and Lublin Province (8.2\%). The smallest share of fixed assets in agriculture in the gross value of fixed assets in total characterises Silesian Province $(1.5 \%)$, thus the region of developed industry and highly developed urbanisation.

The largest values of fixed assets if absolute values is gathered in the sector of bioeconomy of the Wielkopolska Province - PLN 21 bn, Mazovia Province - PLN 20.1 bn, and Lublin Province - PLN 12 bn. On the other hand, the smallest values are in Lubuskie, Opole, Świętokrzyskie, and Silesia provinces (below PLN 6 bn).

The table 4 also presents investment expenditure borne in bio-economy against the backdrop of economy generally. The level of investment expenditures in Polish economy in total has exceed PLN 271 bn and expenditures, and expenditures on bioeconomy were approximately PLN 6 bn, which was approximately $2.9 \%$. According to the table, the bio-economy is distinguished by not large share in the total amount of investment expenditures on the whole economy. The largest share of bio-economy in total investment expenditures borne in the whole economy of provinces was characteristic for Podlasie Province - 6.4\%, Warmian-Masuria Province - 5.1\%, Lublin Province $-4.2 \%$. On the other hand, the smallest share was occurring in industrialised and urbanized provinces such as: Silesia, Mazovia, and Małopolska (approx. 1\%). In the rest of the regions, this share fluctuates around national average. There are also distinct differences between provinces concerning investment expenditures borne on the absolute basis. 
The largest expenditure investments in the bio-economy sector were borne in Wielkopolska Province (PLN 897 mil), Mazovia Province (PLN $821 \mathrm{mil}$ ), and Podlasie Province (PLN 166 mil). According to the data presented in the table 4, the share of the whole sector of bio-economy in investment expenditures in the whole national economy in the scale of the country is $2.2 \%$, whereas the share in fixed assets is $4.4 \%$. It means that the renewal of fixed assets in bio-economy is two times slower than in the whole economy.

Table 4. Fixed assets and investment outlays by actual location of investments in 2015 (current prices) [2]

\begin{tabular}{|c|c|c|c|c|c|c|}
\hline \multirow{3}{*}{$\begin{array}{c}\text { Specification/ } \\
\text { Province }\end{array}$} & \multicolumn{3}{|c|}{ Fixed assets } & \multicolumn{3}{|c|}{ Investment outlays } \\
\hline & \multicolumn{2}{|c|}{ Total } & \multirow{2}{*}{$\begin{array}{l}\text { Agriculture, } \\
\text { forestry and } \\
\text { fishing } \\
\text { in } \% \text { of total }\end{array}$} & \multicolumn{2}{|c|}{ Total } & \multirow{2}{*}{$\begin{array}{c}\text { Agriculture, } \\
\text { forestry and } \\
\text { fishing } \\
\text { in } \% \text { of total }\end{array}$} \\
\hline & $\operatorname{mln} \mathrm{zl}$ & $\%$ & & mln zł & $\%$ & \\
\hline Poland & 3471800.9 & 100.0 & 4.4 & 271839.3 & 100.0 & 2.2 \\
\hline Dolnośląskie & 276655.1 & 8.0 & 3.2 & 22660.5 & 8.3 & 1.8 \\
\hline Kujawy -Pomerania & 155317.3 & 4.5 & 6.2 & 13971.1 & 5.1 & 2.4 \\
\hline Lublin & 151490.8 & 4.4 & 8.2 & 10366.3 & 3.8 & 4.2 \\
\hline Lubuskie & 97568.0 & 2.8 & 3.9 & 5874.3 & 2.2 & 3.4 \\
\hline Łódź & 216320.5 & 6.2 & 5.1 & 17437.7 & 6.4 & 2.2 \\
\hline Małopolska & 258678.7 & 7.5 & 2.9 & 21158.3 & 7.8 & 1.2 \\
\hline Masovia & 715544.9 & 20.6 & 2.8 & 58041.4 & 21.4 & 1.4 \\
\hline Opole & 81693.6 & 2.4 & 6.8 & 8052.6 & 3.0 & 2.8 \\
\hline Subcarpathia & 152880.4 & 4.4 & 4.7 & 11001.5 & 4.0 & 2.1 \\
\hline Podlasie & 91087.0 & 2.6 & 10.7 & 6848.3 & 2.5 & 6.4 \\
\hline Pomerania & 196479.8 & 5.7 & 3.4 & 16772.3 & 6.2 & 2.0 \\
\hline Silesia & 417408.3 & 12.0 & 1.5 & 29502.9 & 10.9 & 0.7 \\
\hline Świętokrzyskie & 89249.3 & 2.6 & 6.4 & 5826.0 & 2.1 & 2.9 \\
\hline Warmian-Masuria & 102145.2 & 2.9 & 8.7 & 8057.1 & 3.0 & 5.1 \\
\hline Wielkopolska & 319161.2 & 9.2 & 6.6 & 25329.0 & 9.3 & 3.5 \\
\hline West Pomerania & 150120.7 & 4.3 & 5.0 & 10940.0 & 4.0 & 3.1 \\
\hline
\end{tabular}

\section{$5 \quad$ Added value of the bio-economy sector and the productivity of labour}

The table 5 presents the amount of a gross added value produced in the bio-economy sector. Analysis of the data included in the table 5 allows to determine the significance of bio-economy in the national economy considering regional differences. In 2014, the highest share of bio-economy, approximately $7.4 \%$, in the 
gross added value generated in the province was achieved in Podlasie Province (PLN 2.5 bn in absolute values). On the other hand, the smallest share in the generation of gross added value of the region was noted in case of agriculture in Silesia Province (0.7\%), Lower Silesia Province (1.4\%), and Małopolska Province (1.4\%). In Mazovia

Table 5. Gross value added in 2014 (current prices) [2]

\begin{tabular}{|c|c|c|c|c|c|c|c|}
\hline \multirow[t]{2}{*}{$\begin{array}{l}\text { Specification/ } \\
\text { Province }\end{array}$} & \multicolumn{2}{|c|}{ Total } & \multicolumn{2}{|c|}{$\begin{array}{l}\text { Agriculture, } \\
\text { forestry and } \\
\text { fishing }\end{array}$} & \multirow{2}{*}{$\begin{array}{l}\text { Agricul- } \\
\text { ture } \\
\text { forestry } \\
\text { and } \\
\text { fishing }\end{array}$} & \multirow{2}{*}{$\begin{array}{c}\text { Industry } \\
\text { and } \\
\text { construc- } \\
\text { tion in } \\
\% \text { of } \\
\text { total }\end{array}$} & \multirow[t]{2}{*}{$\begin{array}{l}\text { Servi- } \\
\text { ces }\end{array}$} \\
\hline & mln zl & $\%$ & mln zl & $\%$ & & & \\
\hline Poland & 1524940 & 100.0 & 43419.0 & 100.0 & 2.8 & 34.3 & 62.8 \\
\hline Dolnośląskie & 129050 & 8.5 & 1777.0 & 4.1 & 1.4 & 41.9 & 56.7 \\
\hline $\begin{array}{l}\text { Kujawy - } \\
\text { Pomerania }\end{array}$ & 67434 & 4.4 & 3006.0 & 6.9 & 4.5 & 36.5 & 59.1 \\
\hline Lublin & 59477 & 3.9 & 3147.0 & 7.2 & 5.3 & 28.5 & 66.2 \\
\hline Lubuskie & 34061 & 2.2 & 1294.0 & 3.0 & 3.8 & 40.8 & 55.4 \\
\hline Łódź & 93091 & 6.1 & 3588.0 & 8.3 & 3.9 & 37.1 & 59.0 \\
\hline Małopolska & 118826 & 7.8 & 1675.0 & 3.9 & 1.4 & 32.5 & 66.1 \\
\hline Masovia & 338437 & 22.2 & 8935.0 & 20.6 & 2.6 & 25.4 & 72.0 \\
\hline Opole & 32267 & 2.1 & 1049.0 & 2.4 & 3.3 & 40.1 & 56.7 \\
\hline Subcarpathia & 59719 & 3.9 & 986.0 & 2.3 & 1.7 & 38.0 & 60.3 \\
\hline Podlasie & 34233 & 2.2 & 2530.0 & 5.8 & 7.4 & 29.5 & 63.1 \\
\hline Pomerania & 86749 & 5.7 & 2093.0 & 4.8 & 2.4 & 34.1 & 63.5 \\
\hline Silesia & 189378 & 12.4 & 1395.0 & 3.2 & 0.7 & 42.5 & 56.7 \\
\hline Świętokrzyskie & 36611 & 2.4 & 1506.0 & 3.5 & 4.1 & 35.3 & 60.6 \\
\hline $\begin{array}{l}\text { Warmian- } \\
\text { Masuria }\end{array}$ & 40960 & 2.7 & 2519.0 & 5.8 & 6.1 & 33.9 & 60.0 \\
\hline Wielkopolska & 147596 & 9.7 & 6011.0 & 13.8 & 4.1 & 36.7 & 59.2 \\
\hline West Pomerania & 57052 & 3.7 & 1908.0 & 4.4 & 3.3 & 31.1 & 65.6 \\
\hline
\end{tabular}

Province, despite low share of agriculture in the structure of the gross added value in total, the added value in absolute terms has exceed PLN 8.9 bn. Apart from Mazowsze, high added value in agriculture has been created also in the agriculture of Wielkopolska - PLN 6 bn and Łódź - PLN 3.5 bn.

Important element of the evaluation of the regional disparity of the bio-economy sector in Poland is the analysis of diversity of the productivity of labour. Productivity of labour is understood as relation between production results and labour resources used. Average level of the productivity of labour measured by gross value added per one person employed in bio-economy in Poland in 2014 was slightly more than PLN 20 thousand (table). In the regional cross-section, the highest productivity of labour in 
agriculture was achieved by West Pomerania Province and Lubuskie Province $(200 \%$ of national average in agriculture, which is approximately PLN 39.4 thousand in nominal terms, and the lowest productivity of labour was achieved in Podkarpackie Province (25\% and PLN 4.9). Productivity of the bio-economy sector in West Pomerania Province was more than 8 times higher than the productivity of bioeconomy in Podkarpackie Province. High level of the productivity of labour in bioeconomy characterised provinces localised in western and north-eastern Poland. However, the lowest level was in the provinces of southern and eastern Poland.

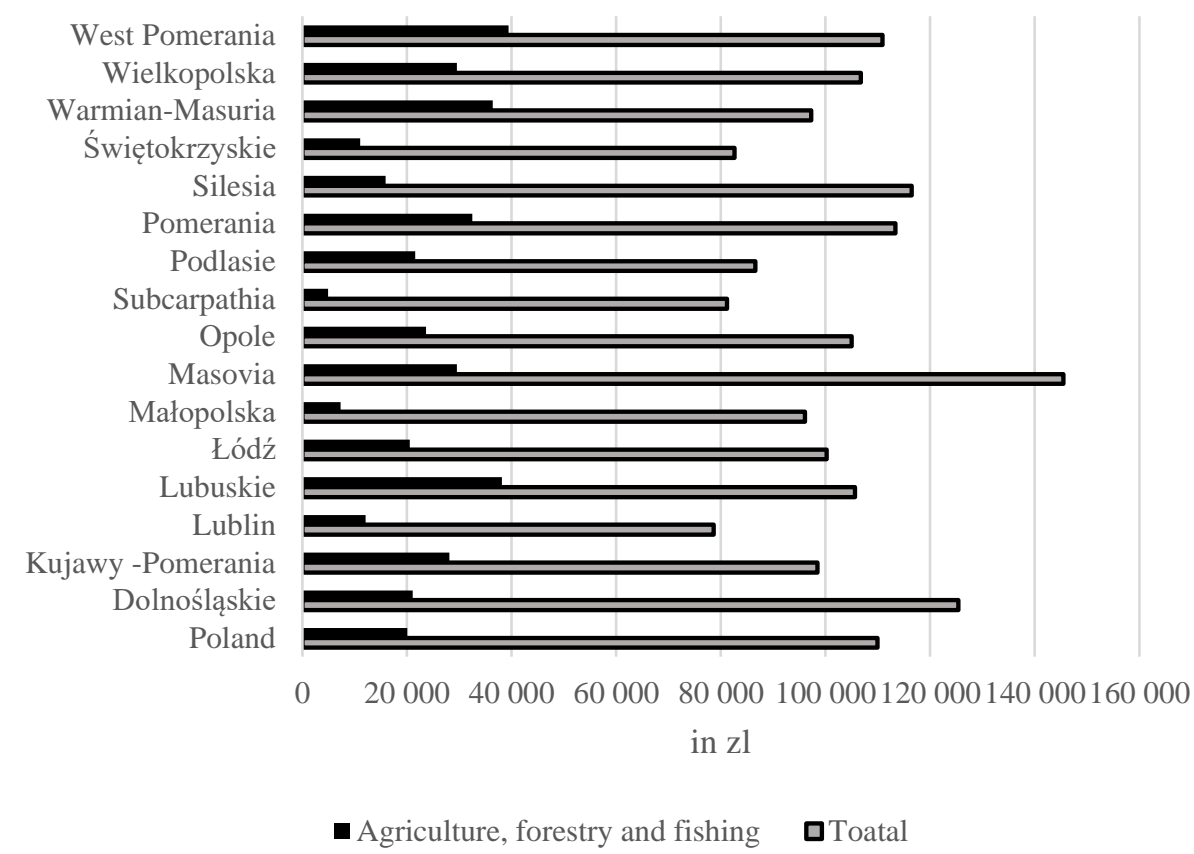

Fig. 2. Gross value added per employed person in 2014. [2]

\section{Summary}

The analysis carried out indicated that bio-economy is an important sector in the national economy. The significance of this area is proven by the share in the employment and production potential.

Comparisons with regions distinguish developed, industrialised, urbanized provinces, in which the share of fixed assets, investments, and added value of bioeconomy is of minor importance in the economy of a region. These are mainly regions of southern and middle Poland: Małopolskie Province, Silesia Province, and Mazovia Province. Silesia and Mazovia provinces belong to the most developed regions in Poland, which has an influence on minor importance of the sectors of bioeconomy in the structure of the economy of those regions. 
Also Wielkopolska Province, which, despite an important significance of agriculture is a well-developed region, belongs to the group of provinces of high level of the development of bio-economy. One of the largest production potentials of agricultural and food sector is concentrated in this region.

The second group of regions constitute provinces located along the eastern border of the EU, namely: Podkarpackie, Podlasie, and Lublin provinces, as well as Świętokrzyskie Province, where bio-economy decides about the situation of regional economy in a great measure.

\section{References}

1. Baran, J.: Gospodarka o obiegu zamkniętym - nowe wytyczne Komisji Europejskiej, Stowarzyszenie Polski Ruch Czystszej Produkcji: http://www.cp.org.pl/2015/12/forum-cpj-baran-circular-economy.html, last accessed 2017/10/27.

2. Central Statistical Office, 2017, Regions of Poland, Warsaw 2017.

3. Directive 2009/28/EC of the European Parliament and of the Council of 23 April 2009 on the promotion of the use of energy from renewable sources and amending and subsequently repealing Directives 2001/77/EC and 2003/30/EC, http://eurlex.europa.eu/eli/dir/2009/28/oj, last accessed 2017/10/28.

4. European Commission (2010), The Knowlede - Based Bioeconomy (KBBE) in Europe. Achivements and Chelleneges. Full conference report. http://cleverconsult.eu/clever3/wpcontent/uploads/2015/02/KBBE_2020_BE_presidency.pdf, last accessed 2017/10/27.

5. European Commission (2012), Commission Staff working Document accompanying Communication on Innovating for Sustainable Growth: A Bioeconomy for Europe. SWD (2012), 11 final

6. European Commission (2012), Communication from the Commission to the European Parliament, the Council the European Economic and Social Committee and the Committee of the Regions. Innovating for Sustainable Growth: A. Bioeconomy for Europe. COM (2012), 60 final

7. European Technology Platforms (2011). The European Bioeconomy in 2030. Deliversing Sustainable Growth by addressing the Grand Societal Challeanges, The White Paper BECOTEPS - $\quad$ Bio-Economy Technology Platforms, http://www.plantetp.org/system/files/publications/files/the_european_bioeconomy_brochu re_web_final.pdf, last accessed 2017/10/28.

8. Gołębiewski, J.: Zrównoważona biogospodarka - potencjał i czynniki rozwoju, (w) Problemy rozwoju rolnictwa i gospodarki żywnościowej w pierwszej dekadzie członkostwa Polski w UE, Polskie Towarzystwo Ekonomiczne, Warszawa (2015).

9. Gołębiewski, J., Pająk, K.: A sustainable bioeconomy in Europe - the European Union's policy and strategy, (w) Political Rents of European Farmers in the Sustainable Development Paradigm. International, national and regional perspective, Polish Scientific Publishers, Warsaw, (2016).

10. Kołodziejczak, M.: Zróżnicowanie regionalne rolnictwa w Polsce i w Niemczech, Problemy Rolnictwa Światowego, T.4 (19), 270-280, (2008).

11. Opinion of the Committee of the Regions on "Innovating for sustainable growth: a bioeconomy for Europe" 2013/C 17/09, http://www.oulu.fi/sites/default/files/news/Opinion\%20of\%20the\%20Committee $\% 20$ of $\% 2$ 0the\%20Regions\%20- 
\%20Innovating\%20for\%20sustainable $\% 20$ growth $\% 20$ a $\% 20$ bioeconomy $\% 20$ for $\% 20$ Europ e.pdf, last accessed 2017/10/27

12. Sillanpaa, M., Ncibi, Ch.: A Sustainable Bioeconomy. The Green Industrial Revolution, Springer International Publishing AG, (2017).

13. Van Leeuwen, M., van Meij, H., Smeets, E., Tabeau, E.: Overview of the Systems Analysis Framework for the EU Bioeconomy, SAT-BBE project, Report D 1.4, Wageningen (2013), http://www3.lei.wur.nl/BerstPublications/SAT-BBE\%20\%20WP1\%20-\%20Deliverable\%201\%204_\%20(FINAL)_20131118.pdf, last accessed 2017/10/28.

14. Zika, E., Papatryfon, I., Wolf, O., Gómez-Barbero, M., Stein, A.J., Bock, A. K.: Consequences, Opportunities and Challenges of Modern Biotechnology for Europe, European Commission, Joint Research Centre, Institute for Prospective Studies, Seville, ftp://s-jrcsvqpx 102p.jrc.es/pub/EURdoc/JRC44144.pdf, last accessed 2017/10/27 